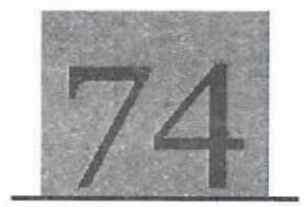

\title{
Survey of the present and fast disappearing fish species along two rivers in the Niger Delta
}

\author{
Oguntade, O.R./ Oketoki, O.T. / Ukenye, E.A./ \\ Mojekwu, T. O. / Usman, B. A. / Adeleke, M. T.
}

\begin{abstract}
Fisheries resources are on the decline in Nigeria due to over exploitation and inadequate management of her coastal waters. For sustainability of these resources, an adequate knowledge of species composition, diversity and relative abundance of her water bodies must be understood and vigorously pursued. A survey was conducted to determine fish species diversity in Brass and Nun River, Niger delta, Nigeria and the socioeconomic studies carried out io determine the status of endanger or level of disappearance of fish species within study area. The survey identified 53 species from 18 families caught from Brass and Nun stations respectively. The fish diversity ranged from typically freshwater fishes such as Tilapia and Ciarias to brackish species such as Chrysichthys nigrodigitatus and Penaeus species. The most abundant family within catch were the Scianidae, Cichidae and Claridae. A checklist of economically important fast disappearing fish species along the two water bodies was generated. Oil spillage, discharges from industries (industrialization) and the domestic wastes from boundaries settlements (urbanization) and farming activities along the tributaries were among the factors identified to have contributed to low species diversity and fast disappearance of certain species. Data generated from this study would serve as baseline information for fisheries resource management.
\end{abstract}

\section{Introduction}

T

The challenge of biodiversity conservation and management is not limited to terrestrial habitat alone but also the aquatic environment. This has therefore generated much interest to various workers (Sugihara, 1980; Marais, 1988; Thiel et al., 2006; Jordan et al, 2010). Watters (1992) reviewed the biodiversity of fresh water fish in relative to habitat. Boulenger (1901-1916) listed 976 species of African freshwater fishes comprising 185 genera and 43 families. Ita (1993) reported 268 different fish species in 34 well known Nigeria freshwater rivers, lakes and reservoirs, which constitute about $12 \%$ of Nigeria's total surface area of about 98,185000 hectares. Allison and Okadi (2013) reported relative abundance of ichthyofuana and species diversity being influenced by variation in mesh size in the lower Nun River. Gillnet selectivity had been reported by Sikoki et al. (1998). The impact of environmental pollution and other human activities on biodiversity cannot be overemphasized. The negative implication of such is the significant decline in catch in some high valued species. It is on record that in the 1980's, fishing production in the river was less than half of that in the 1950's, and fry-catching production was only one fourth of that in the 1960's (Ita, 1993). Several factors continue rendering fish species endangered or threatened in the coastal waters. The objective of this study was to conduct a preliminary assessment on the status of such species in the Nigerian coastal water and determine the socioeconomic impact of the status of endanger or level of disappearance of such fish species.

\section{Materials and Methods}

The sampling areas is between latitude $4^{\circ} 51^{\prime}$ and $4^{\circ} 54^{\prime} \mathrm{N}$ and longitude $6^{\circ} 11^{\prime} \mathrm{E}$ and $6^{\circ} 13^{\prime} \mathrm{E}$ of Brass and lower Nun River around Anyama Ijaw in Bayelsa State. This study was carried out between May and June. Average physio-chemical characteristics were $\mathrm{pH}(6.3-7.9)$, water temperature $\left(23-32^{\circ} \mathrm{C}\right)$, Dissolved oxygen $(6.5-9.2 \mathrm{mgLG} 1)$ and salinity $(0.0 \mathrm{ppt})$. Different fish species (live or freshly dead) were collected from fishermen at the different landing and were preserved on ice in which they were conveyed to the laboratory for identification and preservation. Questionnaires were administered on 163 fishermen, 145 fish sellers and 25 fish processors to determine level of fish disappearance, time, type of gears in use and possible emergence of new strains/species. 


\section{Results and Discussion}

From the two study areas, total fish species composition comprised of fifty-three (53) individuals from eighteen (18) families (table 1). These species composition showed presence of fresh, marine and brackish water origins. The Sciaenidae and Cichlidae were the most abundant comprising of seven and five species each respectively while the Palaemonidae, Sphyraenidae and Bagridae were the least abundant fish comprising one individual each.

Table 1: Some of the prevalent families/ species across stations

\begin{tabular}{|c|c|c|c|c|}
\hline & Family & Species & Brass & Nun \\
\hline \multirow[t]{7}{*}{1} & Sciaenidae & Pseudotolithus typus & $\sqrt{1}$ & $\sqrt{1}$ \\
\hline & & P. senegalensis & $\sqrt{ }$ & $\sqrt{ }$ \\
\hline & & P. elongates & $\sqrt{ }$ & $\sqrt{ }$ \\
\hline & & P. moorii & $\sqrt{ }$ & $x$ \\
\hline & & P. epipercus & $\sqrt{ }$ & $\sqrt{ }$ \\
\hline & & Pteroscion peli & $\checkmark$ & $\checkmark$ \\
\hline & & P. brachygnathus & $x$ & $\checkmark$ \\
\hline \multirow[t]{3}{*}{2} & Polynemidae & Pentanemus quinquarius & $\sqrt{ }$ & $\sqrt{ }$ \\
\hline & & Galeoides decadactylus & $\sqrt{ }$ & $\sqrt{ }$ \\
\hline & & Polydactylus quadrifilis & $x$ & $\sqrt{ }$ \\
\hline \multirow[t]{5}{*}{3} & Cynoglossidae & Cynoglossus browni & $\sqrt{ }$ & $\checkmark$ \\
\hline & 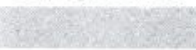 & C. monody & $\sqrt{ }$ & $x$ \\
\hline & & C. senegalensis & $v^{\prime}$ & $\sqrt{ }$ \\
\hline & & C. cadenati & $\sqrt{ }$ & $\sqrt{ }$ \\
\hline & & C. canariensis & $\checkmark$ & $\sqrt{ }$ \\
\hline \multirow[t]{4}{*}{4} & Clupeidae & llisha Africana & $\sqrt{ }$ & $\sqrt{ }$ \\
\hline & & Ethmalosa fimbriata & $\sqrt{ }$ & $\sqrt{ }$ \\
\hline & & Sardinella maderensis, & $x$ & $\sqrt{ }$ \\
\hline & & Pelonula leonensis & $\sqrt{ }$ & $\sqrt{ }$ \\
\hline \multirow[t]{5}{*}{5} & Carangidae & Chloroscombrus chrysurus & $\checkmark$ & $\sqrt{ }$ \\
\hline & & Caranx hippos & $\sqrt{ }$ & $\sqrt{ }$ \\
\hline & & Trachinotus maxillosus & $x$ & $\sqrt{ }$ \\
\hline & & Selene dorsalis & $\sqrt{ }$ & $\sqrt{ }$ \\
\hline & & Caranx crysos & $\sqrt{ }$ & $\sqrt{ }$ \\
\hline \multirow[t]{3}{*}{6} & Penaeidae & Parapenaeopsis atlantica, & $\sqrt{ }$ & $x$ \\
\hline & & Penaeus notialis & $\sqrt{ }$ & $x$ \\
\hline & & Penaeus monodon & $\sqrt{ }$ & $x$ \\
\hline \multirow[t]{3}{*}{7} & Portunidae & Callinectes pallidus & $\sqrt{ }$ & $\sqrt{ }$ \\
\hline & & C. marginatus & $\sqrt{ }$ & $\sqrt{ }$ \\
\hline & & C. amnicola & $\sqrt{ }$ & $\sqrt{ }$ \\
\hline 8 & Palaemonidae & Nematopalaemon hastatus & $\sqrt{ }$ & $\sqrt{ }$ \\
\hline 9 & Sphyraenidae & Sphyraena guachancho & $\checkmark$ & $\sqrt{ }$ \\
\hline \multirow[t]{2}{*}{10} & Lutjanidae & Lutjanus goreensis & $\sqrt{ }$ & $\sqrt{ }$ \\
\hline & & Lutjanus dentatus & $\sqrt{ }$ & $x$ \\
\hline \multirow[t]{7}{*}{11} & Cichlidae & Tilapia guineensis & $x$ & $\sqrt{ }$ \\
\hline & & T. mariae & $\sqrt{ }$ & $\sqrt{ }$ \\
\hline & & T. melanopleura & $\checkmark$ & $\sqrt{ }$ \\
\hline & & Hemichromis fasciatus, & $\sqrt{ }$ & $\sqrt{ }$ \\
\hline & & Sarotherodon melanotheron & $\sqrt{ }$ & $\sqrt{ }$ \\
\hline & & Tilapia dageti (wesaiu) & $\checkmark$ & $\sqrt{ }$ \\
\hline & & Oreochromis niloticus & $\sqrt{ }$ & $\sqrt{ }$ \\
\hline \multirow[t]{2}{*}{12} & Cyprinidae & Labeo senegalensis & $\checkmark$ & $\sqrt{ }$ \\
\hline & & Labeo coubie & $v^{\prime}$ & $x$ \\
\hline \multirow[t]{2}{*}{13} & BAGRIDAE & Chrysichthys nigrodigitatus & $\checkmark$ & $\sqrt{ }$ \\
\hline & & Bagrus docmak & $x$ & $\sqrt{ }$ \\
\hline \multirow[t]{2}{*}{14} & Schilbeidae & Schilbe mystus & $\sqrt{ }$ & $\checkmark$ \\
\hline & . & Schilbe intermedius & $\checkmark$ & $\sqrt{ }$ \\
\hline \multirow[t]{2}{*}{15} & Characidas & Brycinus nurs & $\sqrt{ }$ & $\sqrt{ }$ \\
\hline & & Alester baremozee & $\sqrt{ }$ & $x$ \\
\hline 16 & Mockokidae & Synodontis budjeti & $\sqrt{ }$ & $\sqrt{ }$ \\
\hline 17 & Drepanidae & Drepane africana & $x$ & $\sqrt{ }$ \\
\hline \multirow[t]{2}{*}{18} & Palinuridae & Palinurus regius & $x$ & $\sqrt{ }$ \\
\hline & 18 Families & 53 Species & 44 species & 47 species \\
\hline
\end{tabular}


Table 2: Identified fast disappearing fish species on Nun and Brass water bodies by fisher folks

\begin{tabular}{|c|c|c|c|c|}
\hline Common name & Binomial nomenclature & Family name & Importance & Water body \\
\hline Tilapia & Tilapia guineensis & Chichiidae & Edibie & Nun river \\
\hline Monrovia doctorfish & Achanthurus monroviae & Acanthuridae & Edible & Nun \\
\hline Grey triggerfish & Balistes capriscus & Balistidae & Edible & Nun and Brass \\
\hline Blue spotted trigger fish & Balistes punctuatus & Balistidae & Edible & Brass \\
\hline Wide-eyed flounder & Bothus podas africanus & Bothidae & Edible & Brass \\
\hline Blue spotted cornet fish & Fistularia tabacaria & Fistularidae & Edible & Brass \\
\hline Pink Snrimp & Penaeus notialis & Penaeidae & Edibie & Nun and Brass \\
\hline Bonga shad & Ethmalosa fimbriata & Clupeidae & Edible & Nun \\
\hline Blunt head puffer & Sphoeroides pachygaster & Tetradontidae & Edible & Brass \\
\hline Round stringrays & Taeniura grabata & Dasyatidae & Edible & Brass \\
\hline Giant Allantic mauta & Mauta birostris & Mobulidae & Edible & Brass \\
\hline Greater Guinean & Mobula collloti & Mobulidae & Edible & Brass \\
\hline Violet skate & Raja doutrei & Rajidae & Edible & Brass \\
\hline Bivalves oysters & Crassostrea gazaar & Ostreidae & Edible & Brass \\
\hline Giant sea cattish & Arius gigas & Ariidae & Edible & Brass \\
\hline Cattish & Chrysichthys spp. & Clariidae & Edible & Nun \\
\hline Dolpin & Coryphaena equiselis & Platanistidae & Recreation & Brass \\
\hline Sardines & Sardinelia maderensis & Clupeidae & Edible & Brass \\
\hline Mullet & Liza grandisaquamis \& Mugil curema & Mugilidae & Edible & Nun River \\
\hline African brown snapper & Lutjanus dentalus & Lutjanidae & Edible & Nun \\
\hline Atrican red snapper & Lutjanus agennes & Lutjanidae & Edible & Nun \\
\hline Hammerhead shark & Sphyma lewni & Sphyrinidae & Commercial & Brass \\
\hline Manatee & Trachechus senegalensis & Delphinidae & Commercial & Brass \\
\hline Shiny nose & Polydactylus quadrifilis & Polynemidas & Edible & Brass \\
\hline Synodontis & Synodontis budgetti & Mochokidae & Edible & Nun \\
\hline
\end{tabular}

The 53 species identified belonging to 18 families is an indication of a good biodiversity being highest in the Sciacnidae and Cichlidae. Dominance of Pseudotholythus and Tilapia species may be attributed to gear selectivity. The result is similar to the findings of Allison and Okadi (2009) and Sikoki et al. (1998), who encountered 25 species in 14 families and 24 species belonging to 16 families in the same area of Nun river Niger delta. However, Schilbeidae and Cyprinidae were the dominant families they reported. The presence of these two families (Schilbeidae and $\mathrm{Cy}-$ prinidae) in Nun River and Brass were also reported in this study. But the presence of distichodontidue, gobidae, elopidae, mormyridae, anabantidae were not observed in this work. Conversely, Lutjanidae and Penaeidae, which were not observed in Allison and Okadi (2009), were present in this study.

The fast disappearing species which accompanied low catch in quantity (table 2) identified in the socioeconomic analysis of this study showed that environmental degradation and overfishing are the essential reasons for their disappearance (1/ig. 1). Some other common ones identified by the fisher folks as fast disappearing in local dialect such as sala, gbolo, nda,

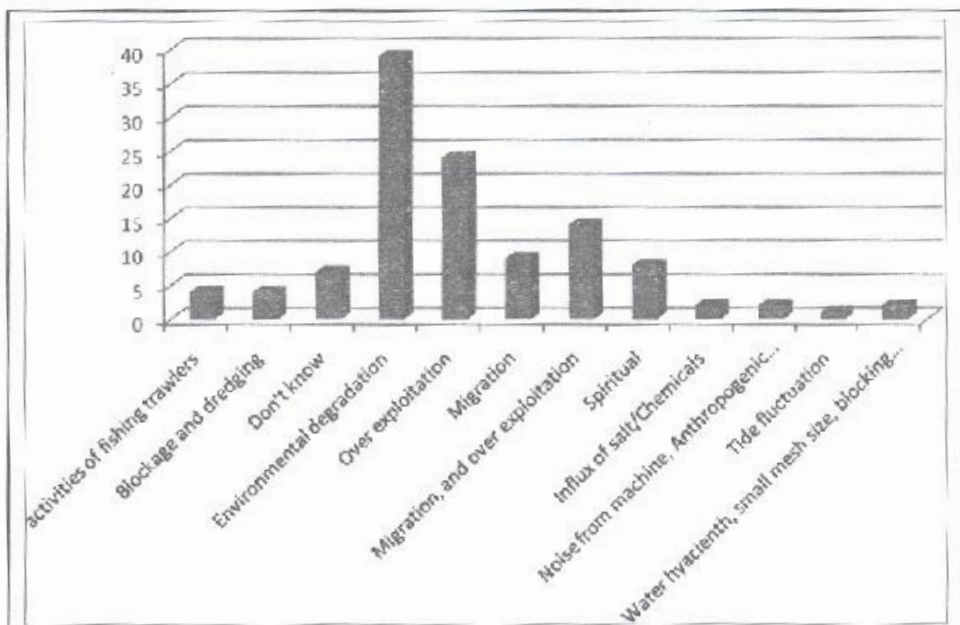

Fig. 1: Reasons for disappearance of important fish stocks. ofoun, benioke, odubemi, tomi, asakabumoun, asakara-bumoun, ikoloko, irim and ekwekwey are yet to be identificd. Recent experience from IUCN (1996) is that wherever fish faunas are studied, more species than suspected turn out to be threatened (i.e. species are at risk of extinction), or cannot be re-recorded at all. The causes of biodiversity loss could be largely related to human factors in the last 5-10 years (figure 2). Gill net was recorded as the most widely used fishing gear in the study area (figure 3). 


\section{Conclusion}

This study complements previous studies on species diversity and abundance distribution in these two important water bodies of the Niger Delta. Fish population are declining as they are been depleted faster than they are ablo to restore their number. This study identified and recommends conservation and friendly environmental approaches as well as socio and economic consideration as a tool to fisheries management to prevent extinction of our valuable fish species. Fishing needs to be limited along the Niger delta coastal area and fish farming should be enhanced to provide for the growing demand among the populace. This will encourage fisheries resources conservation as well as farmed fish production and enhance more jobs for the local people in Nigeria.

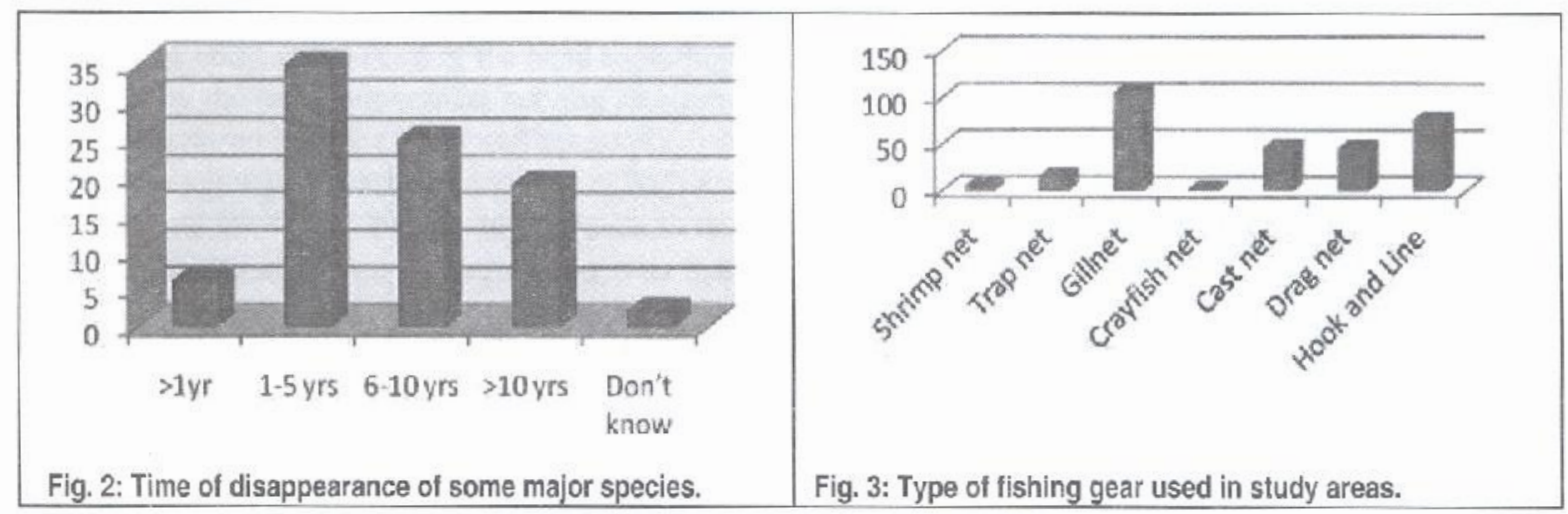

\section{REFERENCES}

Allison, M. E. and Okadi, D. (2013). Gillnet selectivity, seasonal, tidal and photoperiod variation in catch in the lower Nun River, Niger Delta. Nigeria Scientific Research and Essays, 8(3): 108-114.

Allison, M.E. and Okadi, D. (2009). Species distribution and abundancè in the Lower Nun River, Niger delta, Nigeria. Journal of Fisheries International, 1(4):13-18.

Boulenger, G. A. (1901 1916). Catalog of Freshwater Fishes of Africa in the British Museum (Natural History), 5 vols. London: British Museum of Natural History,

Dahiberg, M. D. and Odum, E. P. (1970). Annual cycle of species occurrencc, abundance and diversity in Georgia estuarine fish population. American Midland Naturailst. 83(2): 382-392.

Ita, E. O. (1993). Inland Fishery Resources of Nigeria FAO, CIFA Occasional Paper No. 20, Rome, Italy, FAO. 120.

IUCN (1996). ILCN Red List of Threatened Animals. IUCN Gland, Switzerland, and Cambridge, UK. 448pp.

Jordan, S. J., Lewis, M.A., Harwell, L.M. and Goodman, L.R. (2010). Summer fish communities in Northern Gulf of Mexico estuaries: Indices of ecological condition. Ecological Indicators, 10(2):504-515.

Marais, J.F.K. (1988). Some factors that influence fish abundance in South African estuarine. South African J. Marine Sci, 6/1: $67-77$.

Sikoki, F.D., Hart, A.I. and Abowei, J.F.N. (1998). Gill net selectivity and fish abundance in the lower Nun River, Bayelsa State, Nigeria. Journal of Applied Science and Environmental Management, 11/1:14-19.

Sugihara, G., (1980). Minimal community structure: An explanation of species abundance patterns. American Naturalist, 116/6: $770-787$.

Thiel, R., Sepulveda, A., Kafemann, R. and Nellen, W. (2006). Environmental factors as forces structuring the fish community of the Elbe estuary. Journal of Fish Biology. 46/1: 47-49. 